\title{
ASPECTS OF THE REVELATION OF THE DIVINE IN ST. GREGORY PALAMAS' TREATISE DE OPERATIONIBUS DIVINIS
}

\author{
Christos TEREZIS, ELIAS TEMPELIS* \\ University of Patras, Hellenic Naval Academy
}

\begin{abstract}
In this paper, we examine the concepts 'destination', 'revelation', 'foreknowledge', 'will', 'transmission', 'motion', and 'grace', as they appear in Gregory Palamas' treatise De operationibus divinis. According to the Christian theologian, these terms correspond to specific ways of God's manifestation, i.e. His natural and supernatural revelation. Since they illuminate God's energies, but not His essence, they are participated by the beings of the natural world. The first two terms mainly refer to a general version of the revelation, while the third contains epistemological elements as well and the fourth contains elements referring also to the divine will. The fifth term condenses the content of the afore-mentioned terms seen as an ad extra bestowment. By means of these concepts, Palamas preserves the ontological difference between the supernatural and the natural, while, at the same time, he defines the exact way of their communion, which excludes pantheism. He introduces into the divine realm the state of distinction, which, however, does not restrict its unity at all. He accepts the development of a metaphysical multitude, which is regulated by the divine uniqueness. What emerges is not a kind of Neoplatonic polytheism, but the infinite richness of the divine existence. Thus, Palamas steadily moves within the tradition founded by Ps.-Dionysius the Areopagite, Maximus the Confessor, John Damascene, and George Pachymeres, the main characteristic of which is ontological monism. This is a tradition which formulated common places as to the content, the concepts and the relevant methodology, while the distinction between negative and affirmative theology is dominant.
\end{abstract}

KEY WORDS: Destination, Revelation, Foreknowledge, Will, Transmission, Motion, Grace, Divine essence, Divine energies, Monism

\section{Introduction}

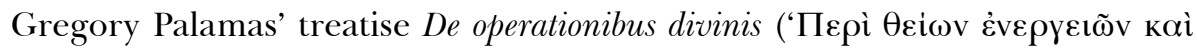

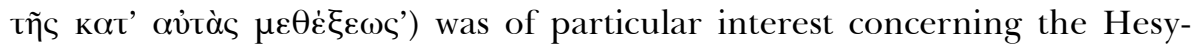
chast controversy. At the same time, this treatise consists in a scientific effort towards the absolutely exact specification of major Christian ontological and

* CHRISTOS TEREZIS (PhD 1985, University of Ioannina) is Professor of Ancient Greek and Byzantine Philosophy at the University of Patras, Greece. Email: terezis@upatras.gr. ELIAS TEMPELIS (PhD 1994, University College London) is Professor of Greek Philosophy at the Hellenic Naval Academy. Email: chrisdar@otenet.gr. 
epistemological doctrines. As is known, it is one of those treatises, which the Archbishop of Thessalonica composed in 1342 with the same topic as to the general theoretical premises, while the second phase of the controversy was in full development with the consecutive persecutions by the Patriarch John Kalekas against him. [Concerning the history of the controversy, cf. Jugie 1931; Meyendorff 1953. For a combination of Gregory Palamas' historical and systematic approach with the era, during which he is active both ecclesiastically and as an author, see Podskalsky 1977: 124-173. As a great achievement of this researcher we stress the exactness of the points he made as to the way Palamas utilized the tradition prior to himself and mainly the tradition of Ps.-Dionysius the Areopagite. More generally, in the above pages we see the whole spiritual construction, which was formulated by the Byzantine thinker.] The main view which is formulated in its contents is that not only the essence of God but also His energies can be called 'deity', without implying the belief in the existence of two or many gods. In what fol-

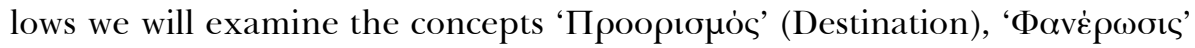

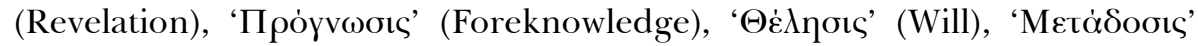
(Transmission), 'Kivnoıs' (Motion), and 'Xópıs' (Grace), as they appear in Palamas' treatise. All seven terms correspond to specific ways of God's manifestation, i.e. His natural and supernatural revelation or His procession

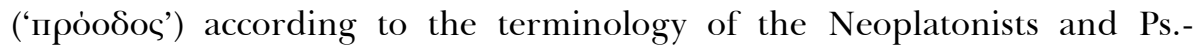
Dionysius the Areopagite. [Within the frame of the Neoplatonic School, the

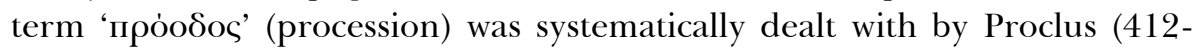
485 A.D.). For instance, cf. Proclus 1963: pr. 25-39, pp. 28.21-42.7 (also Dodds, comm. ad loc., pp. 212-223); Trouillard 1972: 78-106 and 1982: 5391; Beierwaltes 1979: 118-163. Within the frame of Christianity, Ps.Dionysius the Areopagite systematically introduced the concept of 'procession' by means of his treatise De divinis nominibus. Cf. Gersh 1978: 217-229; Corsini 1962: 40-44; Roques 1983: 74-81, 101-111]. They do not denote the essence of God, but His energies manifested through His will and as to their intentional projection, they are participated by the beings of the created world. The first two terms mainly refer to a general version of the revelation, while the third contains epistemological elements as well and the fourth contains elements referring also to the divine will. In the fifth term the content of the first four terms is condensed and is capitalized as an ad extra bestowment. By means of these concepts, Gregory Palamas preserves the ontological difference between the supernatural and the created world, while, at the same time, he defines the exact way of their communion. This is a communion which definitely excludes pantheism. Therefore, the discussion is not about participation, which would introduce the mutation of the same ontological factor into a new kind of hypostasis. All this does not lead to the construction of an ontological pyramid with a hierarchy of superior 
and inferior hypostases, according to the degree they possess a common essential substratum. Thus, Palamas simultaneously introduces into the divine realm the state of distinction, which, however, does not restrict its unity at all. We could, therefore, argue that he accepts the development of a metaphysical multitude. This, however, is regulated by the divine uniqueness, which is founded by means of self-constitutive terms, without external additions. What emerges, after all, is not a kind of Neoplatonic polytheism, but the infinite richness of the divine existence, not only in itself, but also concerning its ad extra renewable projections. Thus, the Hesychast theologian steadily moves within the tradition founded by Ps.-Dionysius the Areopagite, Maximus the Confessor, John Chrysostom, and George Pachymeres. The main characteristic of this tradition is not the naïve ontological monism, but the monism, the energy of which is manifest in many ways, determined by the infinity of the divine (cf., for instance, Hussey 1974). It should be noted that the manifestation of the divine infinity is not subject to any external or internal necessity, but is the projection of an unconditional freedom.

At the same time, our research aims at the formulation of a methodological proposal towards an analytic and synthetic approach to the abovementioned treatise, even within the microcosm of a restricted number of concepts. The proposal refers to the way concepts belonging to the same thematic field, as defined by the author and the tradition he represents, could be classified and analyzed consecutively on the basis of the principles of logic and coherent sequence. According to our proposed classification, we will examine whether each prior concept can consist in the source of the posterior one, which will be considered as the further development of its own source. In accordance with this line of thought, the first two concepts form a unity mainly based on the ontological factor, while the last three form another unity based on the intentional factor. It should be stressed here that within the frame of Eastern Christianity there is no hierarchy but succession between being and will. Such a sequence, anyway, however, clearly reduces a text to a system, to a research project with an internal causation. It should be noted that the treatise De operationibus divinis contains more than forty theological and philosophical concepts, thus proving its theoretical depth. The terms analyzed in Palamas' treatise De operationibus divinis more or less depict his theoretical principles and are mainly divided into two groups. The first group contains terms, like "Ev' (One), 'Movós'

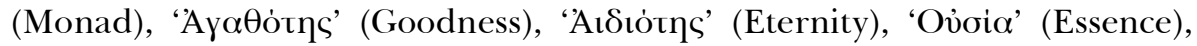

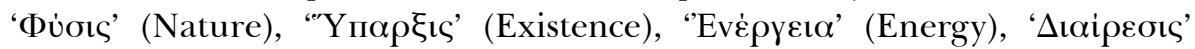



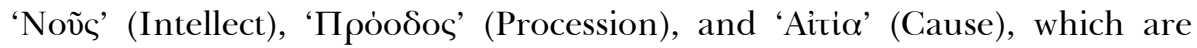
commonly found in the texts of Neoplatonist philosophers. The second 
group consists of terms with a Christian content, like "A $\theta \alpha$ avoia' (Immortal-


(Reign of God), ' $\Theta \dot{\varepsilon} \omega \sigma ı s '$ (Divination), and the terms examined in this paper. Our proposal is characterized as a 'conceptual restructuring' of a text, which possesses a systematic structure and theoretical foundations and formations the content of which is coherent and complete. Through our methodological proposal, we do not attempt to substitute it, but to highlight the possibilities concerning the meanings it contains.

\section{Destination}

A clearly theological term appearing in Palamas' text is 'проорıбuós' (destination). Having a Neoplatonic content, as well, concerning its correspondence to 'providence' (cf. Proclus 1963: pr. 141, pp. 124.19-26), this term denotes the end of a human being which has been imposed by God and appears in the form of the predetermined course which the human being must follow. Its normative function, however, does not at all abolish the human free will. In its heretic version, it is presented as the absolute destination, according to which God absolutely predetermines whom he will vindicate and whom he will condemn, a distinction which excludes human freedom to an absolute degree in all activities and introduces deterministic schemes of salvation. This is a version which finally does not recognize the right of a human being to take any initiative at all, so the authentic moral 'labeling', either positive or negative, is marginalized. Within such a frame, every development is predetermined from the beginning, but this version is absolutely absent from the tradition represented by Palamas.

In his analysis of the term 'проорьouós', Palamas correlates it with the name of God, but stresses that it mainly denotes His properties and energies. This clarification is necessary, since every name used to describe God names some energy and refers to the supernatural being which contemplates and intervenes appropriately according to its own judgment in the totality of what exists. Contemplation consists in some energy, which is a destination and its initial specification is to be realized by the transcendent deity at a time defined by the deity itself. This is the principle of theological kairicity or of the kairicity of divine economy. The destination eternally exists together with the essence of God and is beginningless, uncreated, but not identical with it, because, apart from other metaphysical deviations, pantheism would be introduced (Cf. Palamas 1988b: chapter 8, 102.17-24. The term also appears in Ps.-Cyril of Alexandria 1864: 11, 1145b). The activating demiurgic divine energy would transfer divine essence to the created beings, even indirectly. This would result in the formation of a pyramidlike ontological climax of the same genus, simply constructed in terms of gradations. 
Formulating his syllogism, Gregory Palamas renders clear that God's essence is uncreated, without making His grace as a result consist either in His suprasubstantial essence or in a created being. This distinction is an explicit clause for the avoidance both of simplifying identifications and of any possible downgrading. This remark has a clear ontological purpose, since Barlaam's followers and successors, following a different line of thought, hold that the destination or the destinations are either God's essence or created entities. (Cf. Palamas 1988b: 132.23-133.1. Concerning the theory of Eastern Christianity about unity and distinction within the frame of the Trinity, see Palamas 1988a: 65-95. Cf. Lison 1994: 57-60. With reference to the presence of this theory in Maximus the Confessor, see Töröner 2007). The Byzantine thinker considers this view to be unsubstantiated and unfounded and recalls to memory that the Church Fathers argue with no reservations that the destinations by nature accompany God, i.e. surround His existence and, at the same time, they are uncreated and belong not to the essence, but to the energy of God, as a consequence of the basic belief that God transcends them due to His natural superiority with reference to any relation (chapter 47). As derives from the particular analysis in the following passage, Palamas, after referring to Barlaam's successors, clarifies that he is in accordance with the Fathers:

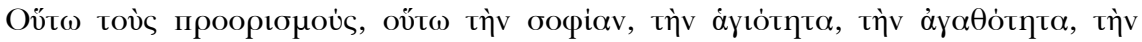

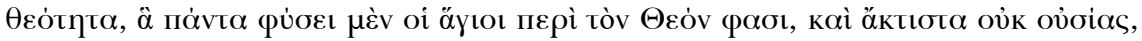

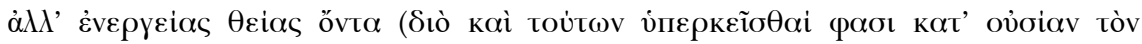

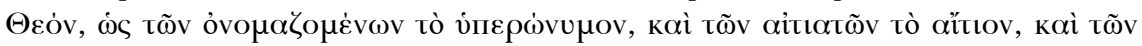

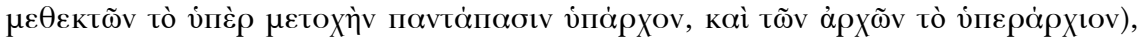

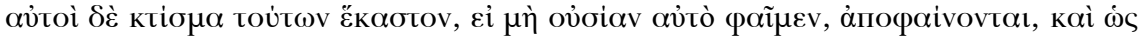

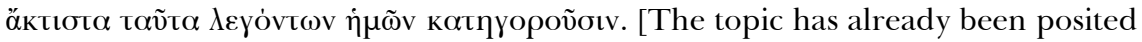
in the fifth chapter of Ps.-Dionysius the Areopagite 1857: 821c. Cf. Semmelroth 1950.]

The human destination is a course predefined by God, but without being compulsory or strictly deterministic. Its main and primary aim is the revelation of His supernatural gifts to the world, a perspective which reaches its summit through the humanization of His Son. The revelation, however, consists, according to the cosmological example of Christianity, in the energy of God's revelation to those people who have the disposition to familiarize themselves with His principles-projections, even though not everybody absorbs it in a mechanistic way.

\section{Revelation}

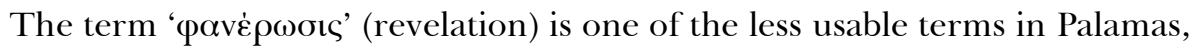
generally denoting the state of every thing's emergence to being or becom- 
ing, the revelation, the transition to a new level of presence. The author in fact identifies the revelation with God's arrival to the world of the created beings. It is the energy of God's revelation particularly to the saints and secondarily to the faithful people (chapter 49). Through this process, the ontological reality which is revealed here, too, is not God as His essence, but His grace and energy through the Holy Spirit, thus showing the divine presence in the natural and historical becoming. Palamas' relevant argumentation derives from the following passage:

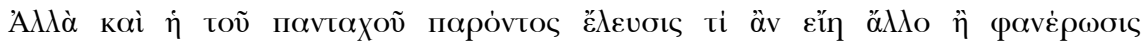

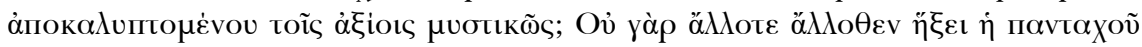

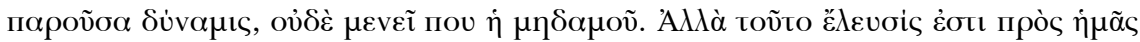

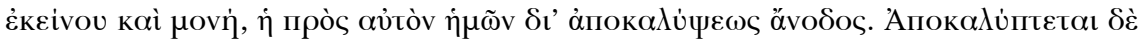

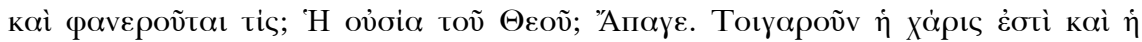

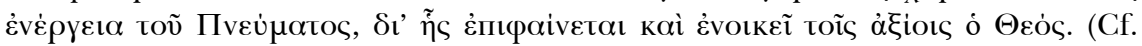

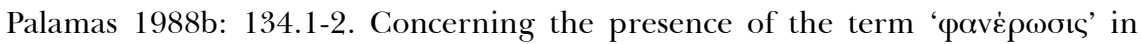
Neoplatonism, cf., for instance, Proclus 1968-97: II, 23.14-25.6.)

The first proof of the revelation of the Holy Spirit in the world of senseperception took place on the river Jordan on the day Jesus Christ was baptized by John, where, apart from the Son and the Holy Spirit 'like a dove', the Father participated as well.

The second proof is on the day of Pentecost, during the descent of the Holy Spirit upon the disciples of Christ and the official foundation of Church, i.e. the historical institution where God and humans meet dialectically and give rise to a new perspective with reference to the eschatological completeness.

It should also be noted that, according to the Church doctrine, the revelation of God takes place continuously, when every faithful person can use in the most appropriate way the gifts of the Holy Spirit, cultivating in their consciousness the thorough acceptance of the benefaction on behalf of the Father-God.

The term 'paví $\rho \omega \sigma ı s$ ' gives shape to the optimistic message concerning God's permanent presence, in the frame of which humans both in the present and the future meet Him and fully participate in His love and providence. This is a condition which broadens the existential horizons of the humans.

The revelation of God to the faithful is considered to be the outcome of His foreknowledge of what He has created. As a whole, the general scheme of divine presence for Gregory Palamas moves within the frame of the personal energy, which derives from the divine nature and is uncreated and without beginning. 


\section{Foreknowledge}

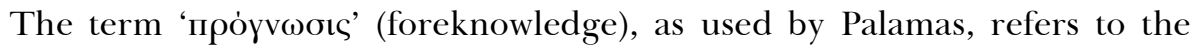
transcendent reality and epistemology, while its application is universal.

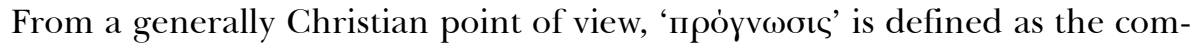
plete knowledge of the future, an epistemological category which exclusively belongs to an absolute degree to God. Given certain conceptual transformations, the term was used by the Neoplatonic School as well, in a way similar to the use employed by the Christians. [Concerning the presence of this term in the texts of the Neoplatonists, cf., for instance, Proclus 1985-86: 88.3; 1908: 123.17; 1960: 37.17, 39.8. Proclus (1968-97: I, 69.9-77.4) presents the thorough knowledge of the supreme principle and the particular gods as connected with their providence for the beings of the world of sense-perception].

Examining the term, Basil the Great analyzes it as expressing the predestined course decided by God with reference to a phenomenon relating to a being. In particular, he argues that God's foreknowledge concerning a particular being consists in the existence of a certain beginning as a constitutive starting point, under the presupposition that there exists an end, which consists in the realization of what was known in advance (Palamas 1988b: chapter 8, 102.25-28. Cf. Basil the Great 1857: 4, 680b). According to this line of thought, we observe by means of specific transformations the course of human history, as an implementation or a non-implementation of this planning. Mankind commences with a preexisting principle, which offers it the logical foundation of creation and its subsequent course. This is human history and will have a particularly conventional end, which at the same time consists in the starting point of future life and of the encounter with God, the divinization at 'the very end of the age'. The teleologicaleschatological example is present here and is reduced to the particular content of the continuously renewed dialectic between the divine and the humans.

Based on his previous reference to one aspect of the term, Gregory Palamas formulates his syllogism by examining the constitutive status of foreknowledge, arguing that it is one of God's natural energies (chapter 9). Foreknowledge is uncreated, without, however, being an essence-nature. It contains all concomitant properties of the divine nature, which are not natures and do not result in even an elementary composition in its internal self. Due to His self-constitutive terms, God is an absolute unity. Consisting in an energy of God, foreknowledge is proven to be without beginning and is not subject to hierarchical specifications (chapter 46). This proof is contained in the following passage in a coherent and concise way: 'A $\lambda \lambda$ ' $\dot{\omega} \varsigma \dot{\varepsilon} \mathrm{K}$

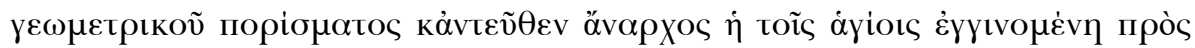

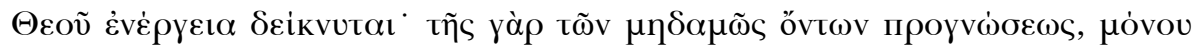




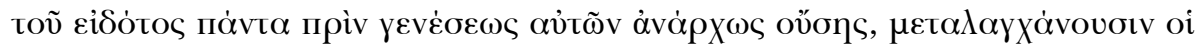

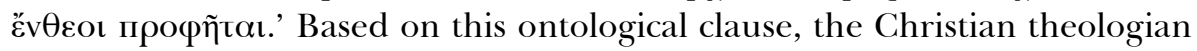
underlines that Barlaam's followers appear to be hesitant concerning this view and formulate their doubts in the form of the following question: "Is foreknowledge a divine essence, which the Lord transmitted to David, as well?». However, in order to prove the absurdity of their views, Gregory Palamas argues that the illuminated prophets accept the gifts from divine foreknowledge. This is distinguished as a way of manifestation only in the transcendent field of the ontological reality which knows everything before its own generation, i.e. of God Himself. The reference is made in order to be shown that the wrong usage of theological terms, whether on purpose or not, leads to an epistemological impasse and to heresies, as in the case of Barlaam the Calabrian and his followers (Palamas 1988b: 132.12-15. Cf. Meyendorff 1959, which is a classical study about Gregory Palamas). As with the other concepts, the Archbishop of Thessalonica posits as a normative principle the implementation of strict epistemological criteria, which are subject to the specifications imposed by the ontological realism, as a distinction in unity.

Since God's foreknowledge expresses the complete knowledge of the future as to the totality of the created world, it entails an intention on his behalf as an agent, the primary goal of which is the realization of a certain fact with specific meanings, in a way analogous to the prevailing circumstances. Thus, His energy or act is proven to be 'purposeful', aiming at securing the domination of the Good in the world of natural and historical becoming, within the perspective of the teleological—eschatological example adopted by the Christian doctrine.

\section{Will}

Palamas also uses ' $\theta \dot{\varepsilon} \lambda \eta$ oıs' (will), a theological term with a clear philosophical meaning since Antiquity. It mainly belongs to the field of moral philosophy denoting that a certain goal is striven for and distinguishing the efforts on behalf of a particular subject or the means the subject uses for the realization of the goal. [For a philosophical examination of will implemented on the way the relation between the divine and the natural universe is defined, cf. Proclus 1903-06: II, 410.8-412.10]. Commencing his syllogisms, the Hesychast theologian tries to correlate God's essence and energy with His will. God's name is of an energy, in the sense that as a metaphysical entity it exists eternally and acts continuously and incessantly. The effects of His energies include whatever can be observed in the surrounding world, i.e. everything that becomes or is a phenomenon. That which becomes is created and the presupposition for its existence is the will of God. The will coexists eternally with God's essence, is beginningless and uncreated, but not the es- 
sence of God, as is accepted by Barlaam's followers, who thus adopt a strict monism (cf. Palamas 1988b: chapter 8, 102.6-103.4).

Examining the topic in a wider sense, we would note that the will denotes a predetermined course, which has been defined on the basis of internal functions to be followed by a subject or an object. However, it belongs to the field of relations, as well. Concerning human beings, God is the supreme agent who defines the course of their existence, the temporal duration of this course and its aim. As this course unfolds, the human subject will go through a series of transitory phases, which are characterized by a mutability attributing correspondingly a degree of relative easiness or difficulty as to the realization of what has been striven for. God's will finally aims at the divination of the humans by grace, their union with their establishing source. Anyway, the possibility of divination will be judged beforehand from the degree the humans themselves will treat these phases from the point of view of their interpretation and action. The continuous struggle for the qualitative improvement of the personal evolution and the denial of the autonomy of the 'self' will lead humans as faithful persons to perfection and, thus, to the realization of the goal of the will.

The theoretical position concerning the divine energies as including the will and the willed, finally aims at expressing the non-existence of the twofold deity and at stressing that through their presence and the way they take place, every Christian must strive by means of their way of life to be reduced to the one, indivisible and con-substantial Trinity, avoiding every subjectively dogmatic or heretic disposition. At the same time, they reflect God's desire to transmit to humans whatever is necessary for their existential fullness. As derives from the following passage, Palamas, in accordance with the doctrine of Maximus the Confessor in the treatise Ad Marinum, ac-

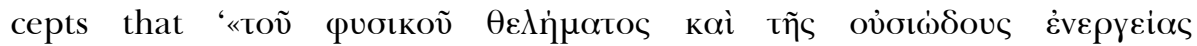

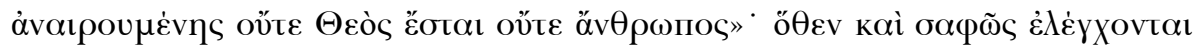

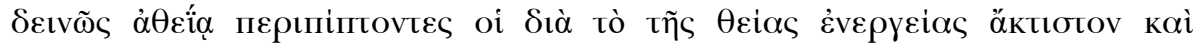

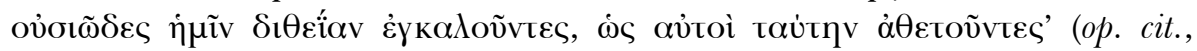
103.16-23; cf. Maximus the Confessor 1865b: $201 \mathrm{a}-\mathrm{b})$. The transition from will to transmission is identified as the most natural outcome.

\section{Transmission}

Palamas also deals with the term ' $\mu \varepsilon t \alpha \dot{\delta}$ oots' (transmission), the specification of which is clearly Neoplatonic. It denotes the transfer of motion from a particular subject or object to another. Developing his argumentation, the Christian theologian relates transmission with the way of God's existence. He argues that God presents Himself by means of His providential procession. This revelation, however, means that to one He appears as a message of wisdom, to another as a message of knowledge, to another as faith and 
gift of healing and so on with reference to any particular gift. The form of these distinctions consists in the multifaceted energy of God, which is analogically multiplied by means of His self-sufficient and inexhaustible goodness. What comes to the fore is not a mechanistic standard example implemented in theology and anthropology, and, of course, no strict standardizations apply. Due to the above distinctions, the transmissions have the presuppositions to characterize the properties of Jesus Christ's divine activity as a human, i.e. His ability as a God-man to attribute divine character as well to His works. In the case, we refer to works of this kind, the Father and the Spirit do not participate, apart from their philanthropy and favor, which took place in the Incarnation, the most important phase of divine economy. This means that the other two persons of the Holy Trinity do not acquire temporality or historicity (Palamas 1988b: Chapter 3, 97.18-98.27; cf. Ps.Dionysius the Areopagite 1857: II, 6, 644c). This is a topic systematically dealt with by Palamas (1988a), where the Incarnation is characterized as a distinction within the frame of the Trinity.

Alternatively, the term ' $\mu \varepsilon \tau \dot{\alpha} \delta$ Oooıs' is examined from the point of view of the reign of God, the content of which is both timely and eschatological. Utilizing fragments from Maximus the Confessor's Capita Theologica, Palamas argues:

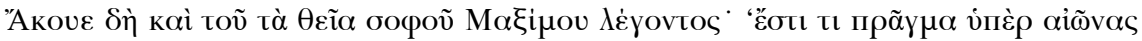







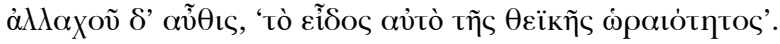

According to Maximus the Confessor, the reign of God is a state which transcends even the centuries, i.e. the absolute transcendent states, and thus is not subject to temporal restrictions (Maximus the Confessor 1865a: 2, 86, $1165 \mathrm{a}-\mathrm{b}$. In the same text, however, it is stressed that despite its transcendence, the divine reign will be participated by those who will deserve to conquer their salvation and existential fullness). From the anthropological point of view, in essence it is the heritage, so to say, of those who acquire their existential fullness and participate in divine providence. This heritage is called 'natural transmission of the properties of God by grace' or 'divine beauty', because the heavenly Father sends His people through the Holy Spirit gifts, which contain elements of the Beauty, the Good, and, as such, they prove that every Christian is prepared to accept divine salvation. Of particular interest here is that the ontological element is combined with the aesthetic, so that the selected example concerning divine economy is not univocal, but holistic (chapter 17). Formal mechanisms, chance and automations are always absent (Palamas 1988b: 110.1-3. Cf. Maximus the Confessor 
1865a: 2, 93, 1169a, a passage which is cited verbatim. Concerning the presence of the term ' $\mu \varepsilon \tau \dot{\alpha} \delta o \sigma t \varsigma$ ' in Neoplatonism, cf., for instance, Proclus 1968-87: VI, 8.6-9.9).

Thus, it has become clear that for Gregory Palamas the transmission as manifestation of bestowment cannot but be related to the manifestation of God in actuality and appear in many ways, each time aiming at a particular outcome. By means of the plurality of these divine revelations, the participation of all faithful people in the divine energy is possible, a process continuously taking place within the frame of divine economy through the bestowment of gifts by the Holy Spirit.

\section{Motion}

For the transmission of the divine bestowments to the natural world 'motion' needs to be activated. In one of his references to affirmative theology or divine economy, Gregory Palamas uses the term 'motion', thus bringing through its content to the fore the ad extra momentum of the Holy Trinity. In the field of the world of sense-experience this term denotes the propellent energy which contributes to the change of the standpoint of a body in relation to the other bodies, which at that time remain unmoved within space. Evidently, however, such content cannot be attributed to divine motion, which is independent from and transcendent to every condition of space and change. As in other cases, as well, the term receives broader meanings included in the perspective posited by theology, which excludes the transitory processes within the Holy Trinity. At the beginning of his thoughts about motion, the Byzantine thinker relates it with energy, which is equivalent to and not depended upon divine nature-essence. For this reason, he argues that it is the drastic and essential of the divine natureessence. Thus, a form of distinction within the divine comes to the fore, where nature-essence is characterized as active (Palamas 1988b: 112.29-32). It should be noted that Gregory Palamas cites John Damascene (1864:

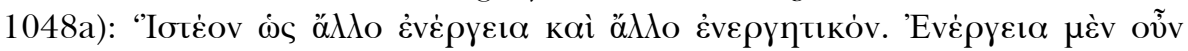

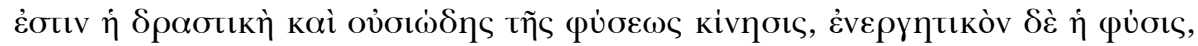

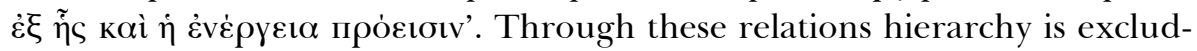
ed.

In another thematic unit, Gregory Palamas relates divine motion with divine energy again, attempting at showing that the term 'differentia' cannot be attributed to both these conditions. Of course, this attribution is possible within the natural world, since the effects of motion are various and cause differentiae as to whatever did not previously exist. It brings to the fore new conditions and changes what was already granted as given. Such a transition to a new ontological condition or development is not logical to appear either in the divine essence or in the manifestations of divine grace, 
which are characterized for their absolute ontological integrity, the foundation of their own selves. Divine motion in this case possesses the place of a way of existence of divine essence, just as it happens exactly with divine power and divine energy. It should be again stressed that it is nowhere underlined that these three conditions are inferior to divine nature-essence. It should be noted that the divine power-energy-motion is not impelled by a certain external factor and does not suffer any intervention, that is, it is not subject to necessities. Its absolute character is preserved, as it exactly also happens with the divine nature-essence (cf. Palamas 1988b: 114.10-14). Here, too, citation is made to the same treatise by John Damascene (1864: 949a). It should be noted that the term 'motion' appears exhaustively in the Neoplatonist Proclus with similar meanings (cf. the emblematic study by Gersh 1973).

Finally, Gregory Palamas relates motion with Jesus Christ's twofold nature, the divine and the human. Therefore, the Incarnated Divine Word has two motions, the justification being that there is no nature without power, energy and motion. It is activated through both motions and, thus, expresses the supreme condition of the divine supernatural Revelation, which functions as a salvation for humans (cf. Palamas 1988b: 114.14-19). Once again, citation is made to the same treatise by John Damascene (1864: 1057a). [Concerning the concept of motion in Christianity, see, indicatively, Gersh 1978: 243-253].

On the basis of what has been exposed so far, it follows that motion, as a dynamic mode of existence of the divine, will be accompanied by personal and intentional conditions. These will clearly be manifested by means of bestowments, which will depict the freedom of their bearer and will aim at the existential fulfillment of their recipients. An expression of this is the term 'grace', by means of which motion is filled by qualitative characteristics and thus any neutral ontology is excluded. On the other hand, the Christian exemplar is teleological in all respects.

\section{Grace of God}

The 'grace of God' ('X⿳亠丷厂巾ı $\Theta \varepsilon o \tilde{v}$ ') is basically a theological term without specific philosophical meanings, which is used by Gregory Palamas particularly in his work De operationibus divinis. According to the Christian doctrine this term generally denotes the eternal manifestation of God's love and mercy to humans, already since the time of their creation as a natural species of a particular constructive nature, evidently rational. Simultaneously and in a specific way there is an expression of the salvational-teleological work which takes place in every human being through Jesus Christ, as depicting the historified Son and Word of God. It is a bestowment which increasingly cultivates the existential quality through the exemplar of Christ, which pre- 
pares for every human being particularly the presuppositions to conquer eternal life. In a way, it is the intervening condition through which the dialectics between the divine and the human develops and enhances, having intentional characteristics far from mechanistic or neutral communications. The Christian theologian initially mentions that the Spirit of God poured out to any natural entity and thus its grace became hypostatized within the created world. However, this ontological 'opening' takes place under the condition that the grace of the Holy Spirit is and eternally remains created and that conclusively it will belong to the ontological category of divine energy and not to that of effects. In order to reaffirm this, Gregory Palamas cites Basil the Great of Caesarea and John the Chrysostom, according to whom the grace of God which pours out is not a produced reality. By means of the utilization of these positions he is led to the conclusive estimation that the divine grace is uncreated, as deriving from the uncreated essence of the three uncreated divine Persons.

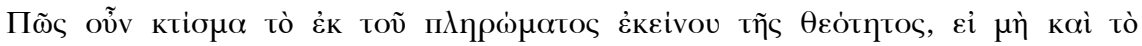

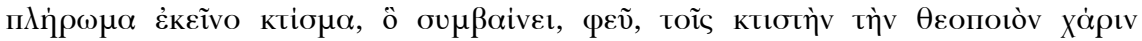

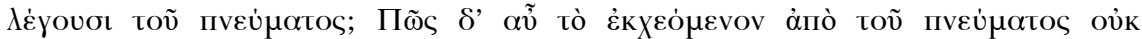

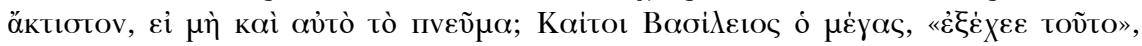

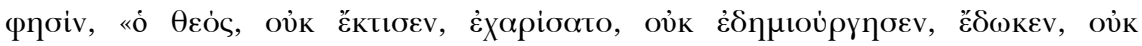

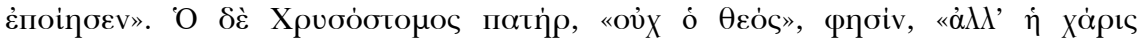

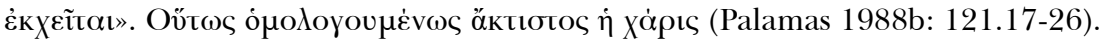

In this passage, Palamas following his usual practice combines the historical and the systematic elements striving by means of this holistic way to reinforce the objectivity of the views he defends. He thus appears as a consistent follower of a formed tradition without any tendency of innovation.

Advancing his syllogisms, Palamas approaches the concept under the anthropological prism and refers to those people who participate in the deifying grace of God. Initially, he argues that, in order to avoid pantheism, every man who receives divine grace possesses its properties by means of participation. Without ceasing to be created and finite according to nature, he becomes uncreated, beginningless and endless according to grace. As Maximus the Confessor emphatically notes, those who are worth participating in this divine projection, become small gods exactly because of the leading ontological content of the grace of God which is emitted. In other words, the timeless becomes immanent in the timely. But those who do not accept the grace of God, exactly on the basis of what the followers of Barlaam argue about themselves, downgrade the deifying donation of the Holy Spirit to something created. In his estimation, these thinkers recognize under such a prism the revelations of this divine Person and, consequently, its supra- 
essential essence. Here the Byzantine thinker is based on the factor of the non-hierarchical distinction of the divine in its unity.





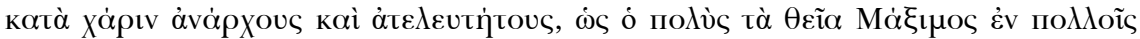

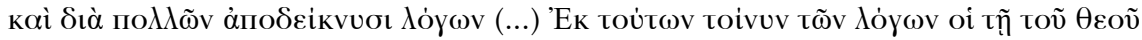

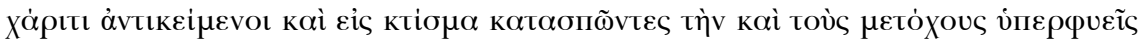

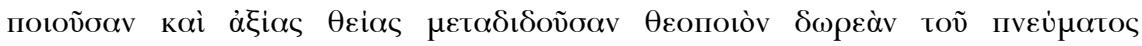

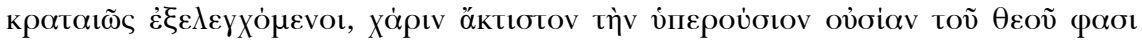
(Palamas 1988b: 122.27-123.2, 123.18-22).

In this passage the concepts used by Palamas are already encountered in the Neoplatonic texts, where the concept of 'participation' is dominant and defines relations and distinctions between the two worlds. However, from the point of view of cosmotheory, the difference of the Christian thinker from the Neoplatonists is clear, since he insists on monotheism and does not adopt polytheism at all.

On the basis of this line of thought, Palamas continues his analysis by stressing that the uncreated grace is not identical as to its particularity with the essence of God, exactly as an extension of the way that his essence is not identical with his uncreated energy. This distinction, in accordance with the context of his general positions, makes clear that ultimately grace is common to the Father, the Son and the Holy Spirit and that through its common manifestation takes place the divinisation of man, which evidently is not due only to one Person.

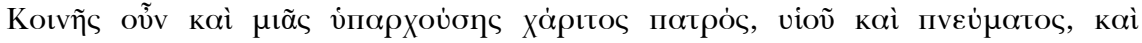

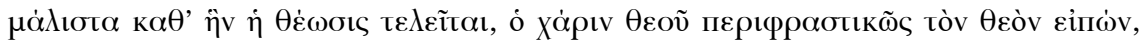

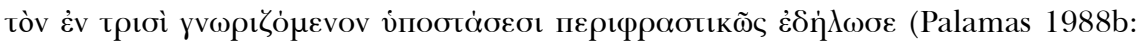
133.12-16).

Apart from having clear ontological orientations referring to the relations of the three Persons of the Holy Trinity, this passage is interesting from the epistemological point of view as well, since it refers to the limits of the hu-


denotes that the most profound being of the divine cannot be depicted by means of exact terms by humans.

He clarifies that Akindynos, as a follower of Barlaam and responsible for more serious theological and logical fallacies, argues that the divine grace is only the Son or the Holy Spirit. We would note that by means of this view these two Persons of the Holy Trinity are clearly downgraded ontologically in relation to the Father. The deviations of Akindynos continue since he cites the argumentation of Maximus the Confessor and estimates that by 
means of a typical denoting of his readings, those who receive the divine grace could be characterized as becoming uncreated. The Hesychast theologian stresses that uncreated is only the divine grace as divine energy and that its distinction from the divine essence is that it functions as participated.

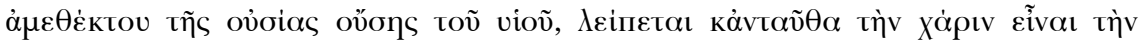

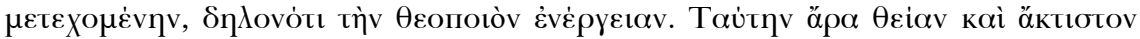

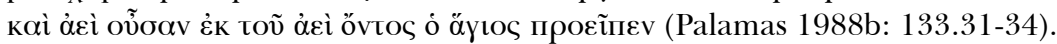

This text excludes any relation of hierarchy within the divine mode of existence.

It should be added that the spiritual circle of Akindynos excludes the uncreated also from the divine grace. He simply uses texts from the Christian tradition in order to underline the theological issues according to his view. According to Palamas the participation in the uncreated does not also denote reception of this property. Man does not cease to remain a man.

In his following syllogism, Palamas moves within the same direction. Initially, he definitely excludes the revelation or the manifestation of the divine essence by any Person of the Holy Trinity. In any case, this is a distinction between the imparticibility of the divine essence-divine Persons and the particibility of the divine grace, which is shown to be established to all those who are worth to participate in the divine charismas. In order to bring to the fore a, so to say, divine functionalism, he stresses that grace derives from the Father and is bestowed by means of the Son.

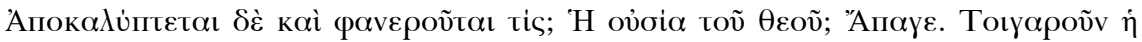

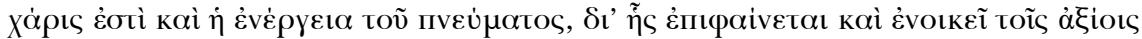

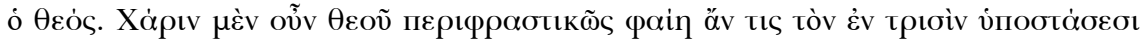

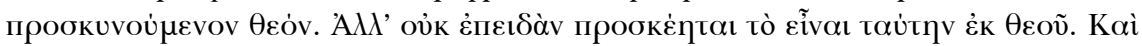

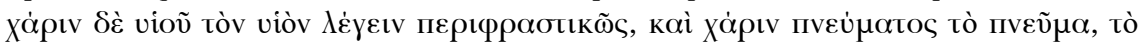

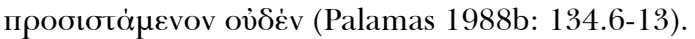

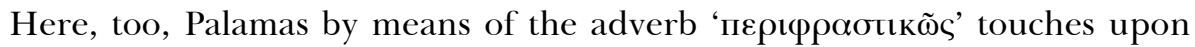
the limits of the human capabilities of cognition and expression.

In any way, however, grace, despite its participable character, preserves its absolutely divine content and is registered, from a certain point onwards, in what we would define as metaphysics of immanence, i.e. within the perspective of divine economy, which by moving in a salvational way, aims at the qualitative transformation of man towards the better.

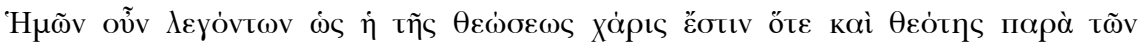

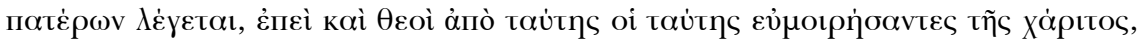

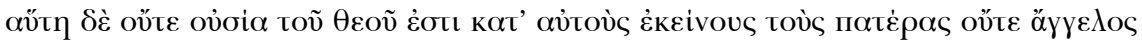




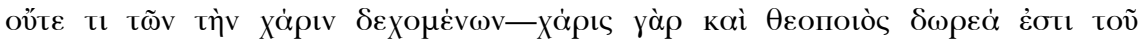

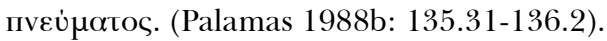

It should be noted that according to a standard tradition in Christianity founded in a structurally systematic way already since Ps.-Dionysius the Areopagite, angels are not gods, but created beings, the cognitive capabilities of which as to the knowledge of the divine are restricted. It should generally be noted that the tradition of the Christian Church has dealt with the grace of God already since its beginning and this topic is connected with the totality of its theoretical objects. As an indication only, we cite the studies by Lossky (1962), where the grace of God is connected with wider epistemological matters, and Gilson (1969: 85-109, 154-174), where the grace of God is mainly connected with divine providence. It should be noted that the latter researcher mainly uses theologians from the Christianity of the West, while frequent and well-targeted are his references to the ancient Greek philosophy, as well.

\section{Conclusions}

The following conclusions can be drawn from the present study:

(a) Palamas' dogmatic and at the same time apologetic treatise De operationibus divinis could consist in a complete and coherent theological and, to some extent, philosophical handbook, throughout a certain conceptual and thematic restructuring. It contains all those terms which are necessary for the foundation of the dogmatic doctrine of Eastern Christianity, with its necessary logical branches. The conceptual richness was particularly important at an opportune time, since this treatise was composed during a period in which the Christian Orthodox tradition had exactly clarified its aims and had incorporated its teaching in its necessary conceptual frames. Thus, it consists in a system of knowledge with a solid foundation and an internal causation; therefore, it possesses the presuppositions to formulate its argumentation, in contrast to all other Christians who choose different theoretical routes.

(b) As a whole, the treatise is to a large extent based on philosophical material from the Platonic, the Aristotelian and the Neoplatonic tradition, even though the character of the concepts we have examined in this paper is rather clearly Christian. This support is undoubtedly necessary. Even though Christianity has very carefully defined its own references, the assistance on behalf of the Greek thought was necessary at least in terms of language. On the other hand, topics like negative and affirmative theology, the difference between Hence and Thence, the distinction between the transcendent and the productive aspect of the divine are loci communi within the ancient Greek and the theological tradition, while their elaboration reached its summit in the frame of the Neoplatonic School. Thus, one could indirectly but neces- 
sarily include among the desiderata concerning research the question as to whether Palamas' acquaintance with this tradition was immediate or intermediate. This topic should be dealt with carefully concerning all Church Fathers, since the dialogue between Hellenism and Christianity in its broad sense is necessary to be exactly defined, even for the sake of the history of philosophy. It should be noted, however, that the existing evidence about his study of a wide range of subjects in Aristotelian philosophy can be easily verified due to the exactness of his use of what belongs to the Aristotelian Organon.

(c) Palamas' theoretical aim which was at stake could be characterized as the rational structuring of metaphysics. His exhaustive use of the terms is not accidental. His text is far beyond the perspective and the requirements of a treatise restricted to dogmatic issues and consists in an essay of a wider range with philosophical ambitions and an insistence on methodology. In this sense, we would hesitate to accept that he is absolutely bound by the restrictions of negative and affirmative theology. He formulates premises and syllogisms which can be logically analyzed and are based on argumentation. Therefore, despite the undeniable priority of theological realism, the thinking subject does not remain inactive, but elaborates on the issues of faith with emphasis on details. This elaboration, however, never transcends human limits. It simply touches the transcendent by means of an analogy, which renders the ambivalences legitimate. The mystical dimensions of faith belong to the responsibility of intuitive reduction. This is a topic which the Archbishop of Thessalonica deals with mainly in his treatises under the title Defensio Hesychastarum. Our estimation is that the treatise De operationibus divinis as a whole is of major philosophical interest concerning a topic which, of course, does not abolish at all its divine presuppositions and reductions. Therefore, the presence of the same terms both in the Neoplatonic texts, for instance, and the Christian ones does not mean that they serve the same theoretical purpose. After all, the Neoplatonists adopt the polytheistic system, while the Christians adhere to monotheism.

As a general epilogue, we cite Vladimir Lossky's following remark, which defines the range of human knowledge as is affirmed in the Christianity both of the East and the West:

L'intellect ne pourra montrer in via sa superiorité sur la volonté, s'il ne renonce à la connaissance. En effet, comme fin dernière où les êtres doués d'intelligence trouveront leur repos, Dieu ne peut être connu que dans la ténèbre et par l'inconnaissance. Dans cette perspective de l'ascension vers un terme transcendant toujours cherché et jamais trouvé, la théognosie de Maître Eckhart se rencontre avec l'apophase extatique de Gregoire de Nysse, inconnue aux occidentaux du vive siècle (Lossky 1998: 196). 
The Hesychast theologian moves with strict consistency within this frame, without abolishing the efforts of human composition. He preserves exactly what we would characterize as theological realism.

\section{Bibliography}

Basil the Great (1857) Contra Eunomium. In Migne JP (ed) Patrologia Cursus Completus (Series Graeca), Paris: Imprimerie Catholique, volume 29, pp. 497-774.

Beierwaltes W (1979) Proklos: Grundzüge seiner Metaphysik. Philosophische Abhandlungen. Frankfurt am Main: Klostermann.

Corsini E (1962) Il trattato de divinis nominibus dello Pseudo-Dionigi e i commenti neoplatonici al Parmenide. Torino: Università de Torino.

Gersh S (1973) Kivqoıs áxivqtos: a study of spiritual motion in the philosophy of Proclus. Leiden: E.J. Brill.

Gersh S (1978) From Iamblichus to Eriugena. Leiden: E.J. Brill.

Gilson É (1969) L' esprit de la philosophie médiévale. Paris: J. Vrin.

Hussey HE (1974) The Persons-Energy Structure in the Theology of St. Gregory Palamas. St. Vladimir's Theological Quarterly 18: 22-43.

John Damascene (1864) Expositio fidei orthodoxae. In Migne JP (ed) Patrologia Cursus Completus (Series Graeca), Paris: Imprimerie Catholique, volume 94, pp. 790-1227.

Jugie M (1931) La controverse palamite (1341-1368). Échos d' Orient 30: $397-421$.

Lison J (1994) Lesprit répandu. Paris: Cerf.

Lossky V (1962) Vision de Dieu. Neuchâtel: Delachaux and Nestlé.

Lossky V (1998) Théologie Négative et Connaissance de Dieu chez Maître Eckhart. Paris: J. Vrin.

Maximus the Confessor (1865a) Capita Theologica. In Migne JP (ed) Patrologia Cursus Completus (Series Graeca). Paris: Imprimerie Catholique, volume 90, pp. 1124-1173.

Maximus the Confessor (1865b) Opuscula theologica et polemica ad Marinum. In Migne JP (ed) Patrologia Cursus Completus (Series Graeca). Paris: Imprimerie Catholique, volume 91, pp. 9-285.

Meyendorff J (1953) Les débuts de la controverse hésychaste. Byzantion 23: 87-120.

Meyendorff J (1959) Introduction à l'étude de Grégoire Palamas. Paris: Éditions de Seuil.

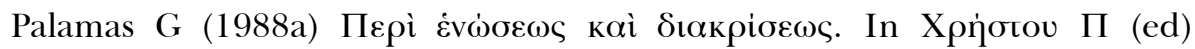

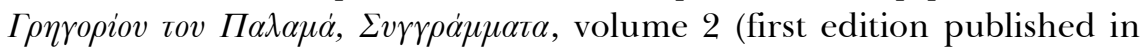

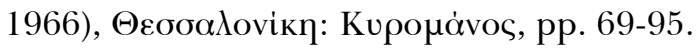




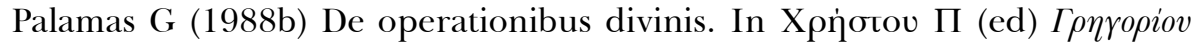

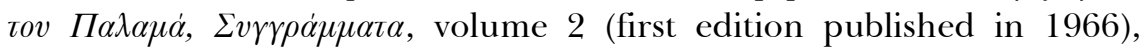



Podskalsky G. (1977) Theologie und Philosophie in Byzanz, München: Becksche Verlagsbuchhandlung.

Proclus (1903-06) In Platonis Timaeum Commentaria. Diehl E (ed). Vols. 13. Leipzig: Teubner, (repr. Hakkert, Amsterdam 1965).

Proclus (1908) In Platonis Cratylum commentaria. Pasquali G (ed). Leipzig: Teubner.

Proclus (1960) De providentia et fato et eo quod in nobis ad Theodorum Mechanicum. In Boese H (ed) Procli Diadochi Tria Opuscula, Berlin: W. de Gruyter, pp. 117-171.

Proclus (1963) Elementatio Theologica. In Dodds ER (ed) The Elements of Theology (repr. 1992). Oxford: Clarendon Press.

Proclus (1968-97) Theologia Platonica. In Saffrey HD and Westerink LG (eds) Théologie platonicienne, vols. 1-6. Paris: Les Belles Lettres.

Proclus (1985-86) In Platonis Alcibiadem I. In Segonds AP (ed) Sur le premier Alcibiade de Platon, Paris: Les Belles Lettres.

Ps.-Cyril of Alexandria (1864) De Trinitate. In Migne JP (ed) Patrologia Cursus Completus (Series Graeca), Paris: Imprimerie Catholique, volume 77, pp. 1119-1174.

Ps.-Dionysius the Areopagite (1857) De divinis nominibus. In Migne JP (ed) Patrologia Cursus Completus (Series Graeca), Paris: Imprimerie Catholique, volume 3, pp. 585-996.

Roques R (1983) L' univers dionysien: Structure hiérarchique du monde selon le Pseudo-Denys. Paris: Aubier.

Semmelroth O (1950) Gottes geeinte Vielheit. Zur Gotteslehre des Ps.Dionysius Areopagita. Scholastik 25: 209-234.

Töröner M (2007) Union and Distinction in the Thought of St. Maximus the Confessor. Oxford: Oxford University Press.

Trouillard J (1972) L' Un et l'âme selon Proclos. Paris: Les Belles Lettres.

Trouillard J (1982) La mystagogie de Proclus. Paris: Les Belles Lettres. 